\title{
ASSESSMENT OF INDIVIDUAL CARDIOVASCULAR RISK AMONG POPULATION IN PUBLIC PHARMACIES USING THE HEART-SCORE QUESTIONNAIRE
}

\section{PROCENA INDIVIDUALNOG KARDIOVASKULARNOG RIZIKA U POPULACIJI U JAVNIM APOTEKAMA KORIŠĆENJEMI UPITNIKA \\ Vesna Maksimovic i Biljana Jakovljević \\ Akademija strukovnih studija Beograd, Odsek Visoka zdravstvena skola, Srbija}

\begin{abstract}
The SCORE model was calibrated according to mortality statistics for each European country. If it is used for the population aged 40-65, it will predict the possibility of fatal cardiovascular consequences that will appear after 10 years. The aim of this study was to investigate individual risk factors for cardiovascular complications in the adult population in the city of Belgrade. The study was designed as a cross-sectional study. Using Heart Score tool for determining of the total risk of $C V D$, could be projected to the age of 60, which may be of particular importance for guiding young adults, aged 20 to 30, with low absolute risk but already with an unhealthy risk profile, which will lead to a much higher risk as they age. In our study, predominately were present female participants without hypertension, then male and were dominate frequent non-smokers compared with smokers in male and female. Furthermore, in study population were more present smokers with longer duration of smoking (>10 years). After calculated Heart Score, we can see that $25.6 \%$ of respondents have a high risk of cardiovascular event, of which $19.6 \%$ high risk, 4.4\% very high risk, and 1.6\% extremely high risk of developing some an adverse fatal cardiovascular event. The present risk factors and high mortality and morbidity from cardiovascular disease indicate the need for taking preventive measures already in children, with the parallel implementation of population strategies and high risk.
\end{abstract}

Keywords: Heart Score, cardiovascular risk, public pharmacies.

\section{SAŽETAK}

Score model upitnika kalibriran je prema statistikama mortaliteta za svaku evropsku zemlju. Ako se koristi za populaciju starosti 40-65 godina, predvideće mogućnost fatalnih kardiovaskularnih posledica koje će se pojaviti nakon 10 godina. Cilj ove studije bio je da istraži pojedinačne faktore rizika za kardiovaskularne komplikacije kod odrasle populacije grada Beograda. Studija je zamišljena kao studija preseka. Korišćenje alata za ocenu srca za određivanje ukupnog rizika od KVB može se projektovati na 60. godinu, što može biti od posebnog značaja za vođenje mladih odraslih, starih od 20 do 30 godina, sa niskim apsolutnim rizikom, ali već sa nezdravim profilom rizika, što će sa starenjem dovesti do mnogo većeg rizika. Unašoj studiji, pretežno su bile prisutne ženske učesnice bez hipertenzije, zatim muškarci $i$ dominirali su često nepušači u poređenju sa pušačima kod muškaraca $i$ žena. Štaviše, u ispitivanoj populaciji bilo je prisutnijih pušača sa dužim trajanjem pušenja (> 10 godina). Nakon izračunatog rezultata za srce, možemo videti da 25,6\% ispitanika ima visok rizik od kardiovaskularnih događaja, od čega $19,6 \%$ visokog rizika, 4,4\% vrlo visokog rizika i 1,6\% izuzetno visokog rizika od razvoja nekog neželjenog fatalnog kardiovaskularnog događaja. Prisutni faktori rizika $i$ visok mortalitet i morbiditet od kardiovaskularnih bolesti ukazuju na potrebu preduzimanja preventivnih mera već kod dece, uz paralelnu primenu populacionih strategija i visok rizik.

Ključne reči: Ocena srca, kardiovaskularni rizik, javne apoteke. 


\section{INTRODUCTION}

Cardiovascular disease are the leading cause of mortality in all region of world, except in Sub - Saharan Africa. It accounts for about $49 \%$ of all deaths and $30 \%$ lost years of life in Europe. They are a significant cause of disability, large health care costs and premature mortality. WHO estimates say that in $2020,70 \%$ of all causes of death will be related to lifestyle, where the most important risk factors are:Unbalanced and improper diet (overweight, obesity), Physical inactivity, Smoking and Alcohol consumption (1-5)

Risk factors for cardiovascular disease are numerous and have cumulatively effect. Most of the risk factors that are associated with the behavior, such as diet and lifestyle, sedentary life at an early age and have a persistent character (6-8). The most significant risk factors that can be prevented are: high blood pressure, smoking, high cholesterol, diabetes mellitus, obesity, inadequate nutrition, and physical inactivity. In stopping the unfavorable trend in CVD, the greatest importance that there should be primary prevention. Patients who have already had a cardiovascular event should be subjected to secondary prevention measures (9-11).

In stopping the unfavorable trend of CVD, primary prevention should be of the greatest importance (12). Patients who have already had an ischemic event should undergo secondary prevention measures, especially in view of advances in the interventional, medical and surgical approaches (1316). Cardiovascular diseases are the most significant cause of death in men and women, and they can be prevented. CVD prevention lasts a lifetime, and the best time to start is before birth, by educating young, future parents, and then should continue in preschool (kindergarten), as well as through failure in the school system. During this phase, the emphasis should be on enjoying a healthy diet and joy and a sense of well-being related to physical activity, instead of focusing on disease prevention. Starting from the 6th grade of primary school (11-12 years, or even earlier, depending on the social environment), a smoke-free lifestyle should be encouraged (17-20).

Secondary prevention is a set of therapeutic measures that reduce the occurrence of recurrent, recurrent cardiovascular events in patients with confirmed atherosclerosis, including coronary heart disease, patients with cerebrovascular disease, peripheral artery and carotid artery disease, and atherosclerotic aortic atherosclerotic disease (21). Equivalents in terms of risk level are people with diabetes, as well as people with chronic kidney disease, and people with asymptomatic atherosclerosis can also be classified in some way (22).

The recommended model for total risk assessment is based on the SCORE (Systematic Coronary Risk Evaluation) system. The SCORE risk assessment is based on a large number of data from prospective European studies and predicts fatal atherosclerotic cardiovascular diseases over a period of 10 years $(23,27)$. This risk assessment is based on the following risk factors: gender, age, smoking, systolic blood pressure, and total cholesterol $(24,25)$. The SCORE model was calibrated according to mortality statistics for each European country. If it is used for the population aged 40-65, it will predict the possibility of fatal cardiovascular consequences that will appear after 10 years $(26,29)$.

The aim of this study was to investigate individual risk factors for cardiovascular complications in the adult population in the city of Belgrade.

\section{PATIENTS AND METHODS}

\section{Ethical Concerns}

This study was performed in accordance with Declaration of Helsinski (1964) and with all relevant ethical guidelines.

\section{Design of study}

The study was designed as a cross-sectional study, with using of a survey or specially designed questionnaire as an instrument. All subjects were adults or more then 18 years old. A questionnaire was created for the needs of the research. The questionnaire consisted of 17 questions, both closed and open. The research was conducted in privately owned pharmacies in the municipalities of New Belgrade, Vracar and Zemun, during January and February 2016. Subjects were selected by random sampling. The survey was anonymous and respondents signed an informed consent form by completing the questionnaire. To determine the sample size, it was estimated that 138 subjects were needed (test power $80 \%$, error level 0.05 ).

As a research instrument, a specially designed questionnaire was used, which consists of 3 parts: the first part presents sociodemographic data on respondents, the second part records of present, already diagnosed diseases in respondents, and the third behavior of respondents, ie detection of personal risk factors for cardiovascular diseases. These three sections applied to all respondents.

\section{Heart Score Tool}

Using Heart Score tool for determining of the total risk of CVD, could be projected to the age of 60 , which may be of particular importance for guiding young adults, aged 20 to 30 , with low absolute risk but already with an unhealthy risk profile, which will lead to a much higher risk as they age (29).

The 2003 guidelines used the SCORE assessment for risk assessment, based on data from 12 European cohort studies; it included 205,178 subjects, surveyed between 1970 and 1988 with 2.7 million years of follow-up and 7,934 cardiovascular deaths. In this way the SCORE risk function was confirmed $(23,29)$.

Risk tables, such as SCORE, aim to facilitate risk assessment in seemingly healthy individuals. Patients who have had a clinical event such as acute coronary syndrome (ACS) 
or stroke automatically qualify for intensive care and risk factor management. SCORE differs from previous risk assessment systems in several important ways, and has been modified to some extent for current guidelines. The SCORE system assesses the risk of 10 years to the first fatal atherosclerotic case, whether a heart attack, stroke, aortic aneurysm, or some other (29).

\section{Statistical analysis}

The collected data were then coded and entered into Microsoft Excel 2016. The statistical program Excel 2016 was used for descriptive data analysis. PASW v18 was used for regression analysis.

\section{RESULTS}

Demographic characteristic of study population

In Table 1 are shown basic data about study population.

We observed distribution of location of public pharmacies, age, gender, marital status and education level of participants.

Table 1. Distribution of basic demographic characteristic in study population

\begin{tabular}{|c|c|c|c|c|c|}
\hline \multirow{5}{*}{ City } & & Frequency & Percent $(\%)$ & $\begin{array}{c}\text { Valid Percent } \\
(\%)\end{array}$ & Cumulative Percent (\%) \\
\hline & Zemun & 79 & 31,6 & 31,6 & 31,6 \\
\hline & Novi Beograd & 89 & 35,6 & 35,6 & 67,2 \\
\hline & Vracar & 60 & 24,0 & 24,0 & 91,2 \\
\hline & Other & 22 & 8,8 & 8,8 & 100,0 \\
\hline \multirow{5}{*}{$\begin{array}{c}\text { Age } \\
\text { (years) }\end{array}$} & & Frequency & Percent (\%) & $\begin{array}{c}\text { Valid Percent } \\
(\%)\end{array}$ & Cumulative Percent (\%) \\
\hline & $<30$ & 83 & 33,2 & 33,2 & 33,2 \\
\hline & $31-50$ & 51 & 20,4 & 20,4 & 53,6 \\
\hline & $51-65$ & 30 & 12,0 & 12,0 & 65,6 \\
\hline & $>65$ & 86 & 34,4 & 34,4 & 100,0 \\
\hline \multirow{3}{*}{$\begin{array}{l}\text { Gender } \\
(\mathrm{m} / \mathrm{f})\end{array}$} & & Frequency & Percent $(\%)$ & $\begin{array}{c}\text { Valid Percent } \\
(\%)\end{array}$ & Cumulative Percent (\%) \\
\hline & Male & 93 & 37,2 & 37,2 & 37,2 \\
\hline & Female & 157 & 62,8 & 62,8 & 100,0 \\
\hline \multirow{5}{*}{ Merital status } & & Frequency & Percent $(\%)$ & $\begin{array}{c}\text { Valid Percent } \\
(\%)\end{array}$ & Cumulative Percent (\%) \\
\hline & Not Merried & 94 & 37,6 & 37,6 & 37,6 \\
\hline & Merried & 108 & 43,2 & 43,2 & 80,8 \\
\hline & Divorced & 15 & 6,0 & 6,0 & 86,8 \\
\hline & Widover & 33 & 13,2 & 13,2 & 100,0 \\
\hline
\end{tabular}




\begin{tabular}{|c|c|c|c|c|c|}
\hline \multirow{4}{*}{ Education } & Frequency & Percent (\%) & $\begin{array}{c}\text { Valid Percent } \\
(\%)\end{array}$ & Cumulative Percent (\%) \\
\cline { 2 - 6 } & Primary school & 7 & 2,8 & 2,8 & 2,8 \\
\cline { 2 - 6 } & High school & 130 & 52,0 & 52,0 & 54,8 \\
\cline { 2 - 6 } & Faculty & 113 & 45,2 & 45,2 & 100,0 \\
\hline
\end{tabular}

\section{Hypertension as a cardiovascular risk factor in study population}

In our study, predominately were present female participants without hypertension, then male. Similar, were frequently male and female participants with hypertension (Figure 1). Also, in the same group, we observed the most frequent self-measuring of blood pressure compared with other groups (Figure 2).

Figure 1. HTA distribution in study population

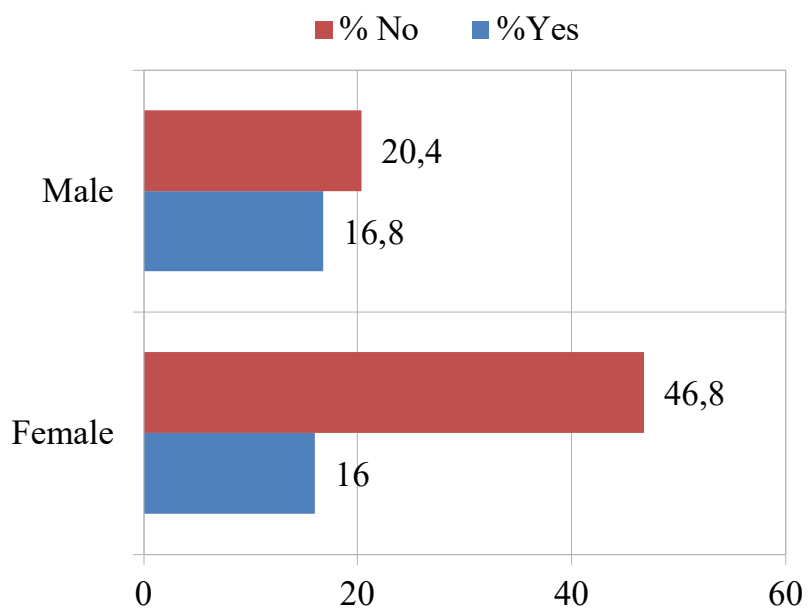

Figure 2 Self-measuring of BP distribution in study population

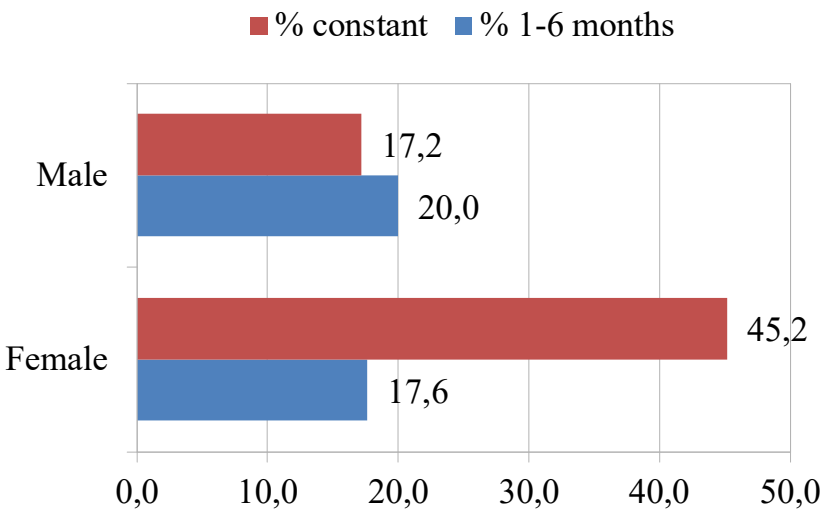

\section{Smoking as a cardiovascular risk factor in study population}

As we can see on Figure 3, in our study were dominate frequent non-smokers compared with smokers in male and female (Figure 3). Furthermore, in study population were more present smokers with longer duration of smoking $(>10$ years) (Figure 4). Also, in smokers group there were higher percent of participants who smoked more than 20 cigarets per day (Figure 5)

Figure 3. Smokers and non-smokers distribution in study population

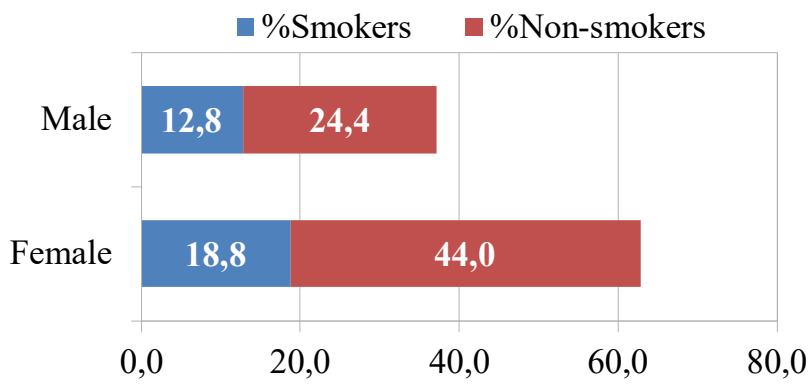

Figure 4. Duration of smoking in participants

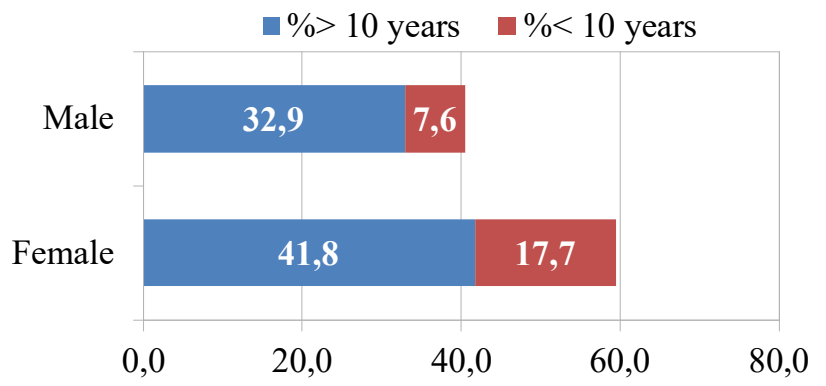

Figure 5. Intensity of smoking in male and female

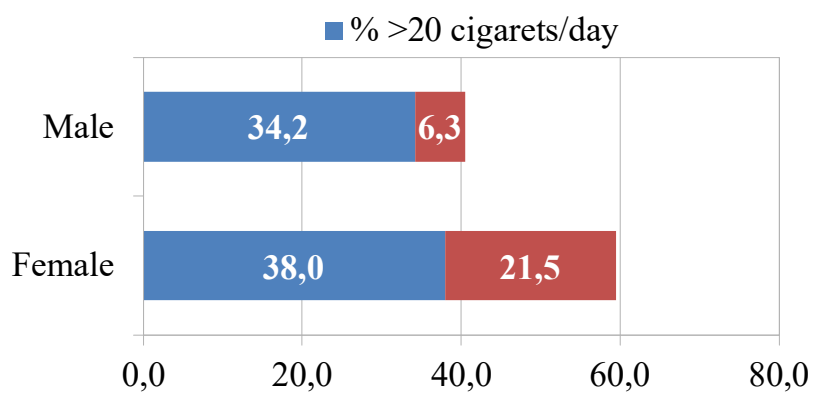


Body weight as a cardiovascular risk factor in study population

Regarding the body weight, we measured waist size and body mass index of each participant. The most frequent were female participant without CVD risk, and the most unfrequent were male participant without risk (Figure 6). Also, BMI below 30 was significantly present in our study population (Figure 7).

Figure 6. Waist size in study population

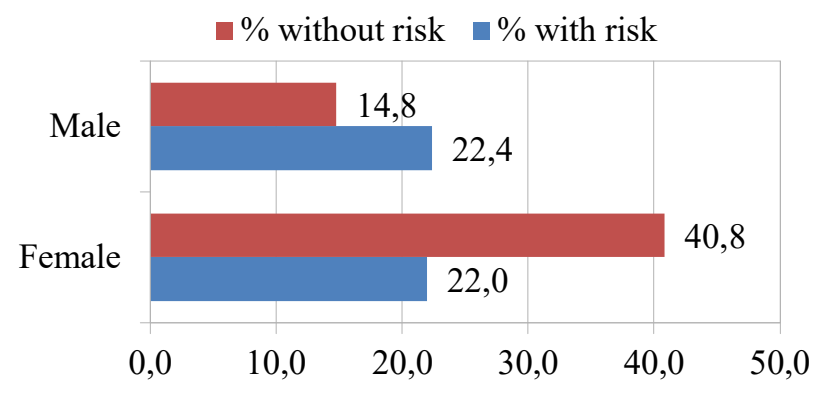

Figure 7. BMI in study population

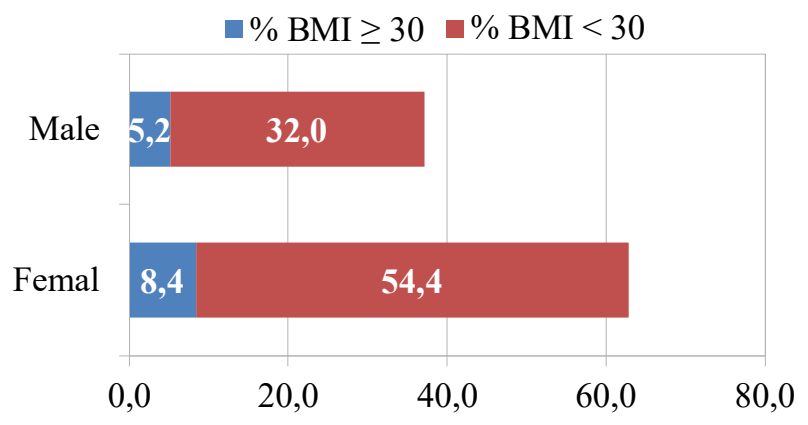

\section{Heart Score in study population}

We categorized participant into two categories: participants with HS higher than 5 and lower than 5. In our study, in $19,6 \%$ were present male with HS higher than 5 and in $6 \%$ were female with higher HS than 5 (Fig. 8). Also, after calculated Heart Score, we can see that $25.6 \%$ of respondents have a high risk of cardiovascular event, of which $19.6 \%$ high risk, $4.4 \%$ very high risk, and $1.6 \%$ extremely high risk of developing some an adverse fatal cardiovascular event. The workload in relation to gender is $52.7 \%$ of all men included in the sample have a high or very high and extreme risk compared to only $6 \%$ of all surveyed women. Using regression analysis, it was found that the factors that have statistical significance for the assessment of Heart Score are as follows: age of subjects $(\mathrm{F}=12,023 ; \mathrm{p}<0,001)$, sex of subjects ( $\mathrm{F}=$ $20,685 ; \mathrm{p}<0,001)$, smoking $(\mathrm{F}=6,249 ; \mathrm{p}=0.003)$ and systolic pressure $(F=10.553 ; p<0.001)$. Other variables had no effect on the Heart Score value.

Regarding the variables, the age of the subjects and the value of systolic pressure, with increasing values, the risk measured by Heart Score also increased, which was to be expected. Men also had a higher risk of an unwanted CV event than women. An interesting result was obtained for the variable smoking in the sense that the respondents who smoked had the highest risk, but on the other hand a higher estimated risk was recorded in respondents who did not smoke than in respondents who recently quit smoking.

Figure 8. Heart Scores in study population

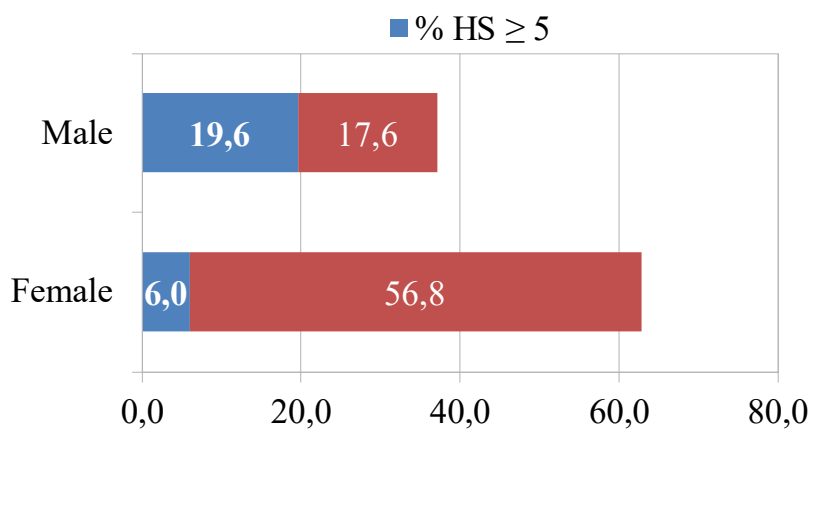

\section{DISCUSSION}

According to the results of the research, more than $1 / 4$ of the examined population of adult inhabitants of the city of Belgrade has a high Heart Score (value higher than 5) (29). Risk factors that affected the value of the Heart Score were: age of the subjects, sex of the subjects, smoking and the value of systolic pressure. Other variables had no effect on the Heart Score value, which can be explained by the relatively small sample examined (14-23).

Cardiovascular diseases are still leading in the number of patients - both in the world and in our country. About 17.3 million people die each year, most often from heart attacks and strokes. These are conditions that can be treated, and it is possible to prevent them. It is best if we deal with our own cardiovascular risk on time. This mostly applies to men over 40 and women over $45(11,30)$.

According to WHO experts, the number of people suffering from CVD will continue to grow from year to year until $2020(15,29)$. These diseases are increasingly affecting the working age population, and their immediate cause is stress, low standard, daily struggle for survival, low level of general awareness and education about the importance of adequate prevention, which, in addition to proper nutrition, physical activity, includes regular visits to check-ups and taking prescribed therapy (31-33).

Mortality, incidence and fatal outcomes of CVD are declining in most countries of northern, southern and western Europe, but either not declining or even rising in Central and Eastern Europe. Although CVD mortality rates are declining in the EU, the number of men and women living with these diseases is growing (34). This paradox is related to increased longevity and improved survival of patients with CVD. The burden of these diseases is unevenly distributed in the world, with higher mortality of people who are in a worse socio- 
economic position. In Serbia, every hour, from various manifestations of CVD, 6 people die, of which every eighth is in the most productive years of life (from 25 to 64 years). Compared to all other causes of death during 2013, 24,505 men (45.9\% of all causes of death) and 28,862 women $(54.1 \%)$ died of heart and blood vessel diseases in Serbia. Compared to 2012 , when the mortality rate from CVD was 763.6 per 100,000 inhabitants, in 2013 the mortality rate dropped to 744.9 per 100,000 inhabitants (32-36).

From 2001 to 2010, the CVD mortality rate in Serbia fell by $14 \%$ for women and by $16 \%$ for men, but despite the registered decline in the mortality rate, Serbia is in the group of countries with a higher-than-average risk for the countries of the European region $(29,36)$. The lack of CVD prevention is evident in the Republic of Serbia. According to a study of the workload of the KVB society (37), Serbia spent much more money on the treatment of cardiovascular diseases and its complications than on prevention; more than $60 \%$ of direct health care costs can be attributed to hospitalizations, surgical and diagnostic procedures. An additional problem in the Republic of Serbia is incomplete or missing data regarding funds invested in prevention activities, such as smoking cessation campaigns.

Alarming trends for chronic diseases, such as obesity, cardiovascular diseases and diabetes mellitus, affect people at the earliest age, which indicates a significant need not only for primary and secondary prevention, but also for primordial prevention. Primordial prevention is defined as preventing the development of risk factors, such as smoking, being overweight or consuming alcohol. Smoking significantly reduces the chances of survival in middle age. Three times the percentage of heavy smokers ( $\geq 20$ cigarettes per day) dies from cardiovascular disease compared to people who have never smoked. The beneficial effect of smoking cessation is more pronounced in earlier years, but it is also present in people who quit smoking in their 50 s or 60 s (38). It has been documented that prevention strategies are not only cost-effective, but also strategies that bring certain savings to the health system. The company's programs aimed at increasing physical activity, improving nutrition, and preventing smoking provide a return on investment in the sense that for every dollar spent, the company returns $\$ 5.6$ within 5 years (57). Smokefree enclosed regulations are also estimated to bring the United States savings in the health care system of $\$ 10$ billion a year $(31,34)$.

Being overweight has also been shown to be an independent risk factor for CVD (58). In Serbia, prevention programs are experiencing a low level of implementation. Even more worrying is the fact that only half of the population has received counseling from health professionals to change life risk factors, but only one third of those have actually changed some of their risk factors. Less than $1 \%$ of smokers used the smoking cessation counseling service (29-34).

However, these diseases can be largely prevented. The WHO estimates that a simultaneous reduction in blood pressure, obesity, cholesterol and tobacco use in the majority of the population would more than double the incidence of CVD (29). The presented risk factors and high mortality and morbidity from cardiovascular diseases indicate the need to take preventive measures as early as possible, with the parallel implementation of population strategy and high-risk strategy. The possibility of risk assessment is a step forward in the prevention of CVD.

\section{CONCLUSION}

The present risk factors and high mortality and morbidity from cardiovascular disease indicate the need for taking preventive measures already in children, with the parallel implementation of population strategies and high risk.

\section{REFERENCES}

1. Mirzaei M, Truswell AS, Taylor R, Leeder SR. Coronary heart disease epidemics: not all the same. Heart 2009;95:740-746.

2. WHO. MONICA monograph and multimedia sourcebook. World s largest study of heart disease, stroke, risk factors and population trends 1979-2002. Tunstall-Pedoe H. ed, 2003.

3. Nacionalni vodič za lekare u primarnoj zdravstvenoj zaštiti, Prevencija kardiovaskularnih bolesti, Republička stručna komisija za izradu i implementaciju vodiča u klinikoj praksi, Ministarstvo zdravlja Republike Srbije 2004.

4. National Institute for Health and Clinical Excellence. Prevention of Cardiovascular Disease: Costing Report. 2010. Nice Public Health Guidance 25.

5. Clark AM, Hartling L, Vandermeer B, McAlister FA. Meta-analysis: secondary prevention programs for patients with coronary artery disease. Ann Intern Med 2005;143:659-672.

6. Doll R, Peto R, Wheatley K, Gray R, Sutherland I. Mortality in relation to smoking: 40 years' observations on male British doctors. BMJ 1994;309: 901-911.

7. Huisman M, Kunst AE, Mackenbach JP. Inequalities in the prevalence of smoking in the European Union: comparing education and income. Prev Med 2005;40: 756764. 22. Edwards R. The problem of tobacco smoking. BMJ 2004;328:217-219. 215.

8. Prescott E, Hippe M, Schnohr P, Hein HO, Vestbo J. Smoking and risk of myocardial infarction in women and men: longitudinal population study. BMJ 1998; 316:1043-1047.

9. World Health Organization. Global Health Observatory Data Repository.

10. O’Leary DH, Polak JF, Kronmal RA, Manolio TA, Burke GL, Wolfson SK Jr. Carotid- artery intima and media thickness as a risk factor for myocardial infarction and stroke in older adults. Cardiovascular Health Study Collaborative Research Group.N Engl J Med1999;340:14- 22. 
11. Chambless LE, Heiss G, Folsom AR, Rosamond W, Szklo M, Sharrett AR, Clegg LX. Association of coronary heart disease incidence with carotid arterial wall thickness and major risk factors: the Atherosclerosis Risk in Communities (ARIC) Study, 1987 - 1993. Am J Epidemiol1997;146:483-494.

12. US Department of Health and Human Services. 2008 Physical Activity Guidelines for Americans. 2008

13. Williams PT. Physical fitness and activity as separate heart disease risk factors: a meta- analysis.Med Sci Sports Exerc2001;33:754-761.

14. American College of Sports Medicine.ACSM's Guidelines for Exercise Testing and Prescription. 8th ed. Baltimore, MD: Lippincott, Williams and Wilkins; 2009.

15. World Health Organization. Obesity: Preventing and Managing the Global Epidemic. Report of a WHO Consultation. World Health Organization Technical Report Series, Report No. 894. 1998.

16. Fry J, Finley W. The prevalence and costs of obesity in the EU.Proc Nutr Soc 2005;64:359-362.

17. Romero-Corral A, Montori VM, Somers VK, Korinek J, Thomas RJ, Allison TG, Mookadam F, Lopez-Jimenez F. Association of bodyweight with total mortality and with cardiovascular events in coronary artery disease: a systematic review of cohort studies. Lancet 2006;368:666-678.

18. Poirier P, Giles TD, Bray GA, Hong Y, Stern JS, PiSunyer FX, Eckel RH. Obesity, cardiovascular disease: pathophysiology, evaluation, effect of weight loss: an update of the 1997 American Heart Association Scientific Statement on Obesity and Heart Disease from the Obesity Committee of the Council on Nutrition, Physical Activity, and Metabolism. Circulation 2006;113:898 918.

19. Freiberg MS, Pencina MJ, D’Agostino RB, Lanier K, Wilson PW, Vasan RS. BMI vs. waist circumference for identifying vascular risk. Obesity (Silver Spring) 2008; 16: 463- 469.

20. Pischon $T$, Boeing $H$, Hoffmann K, Bergmann M, Schulze MB, Overvad K, et al. General and abdominal adiposity and risk of death in Europe. N Engl $\mathrm{J}$ Med 2008;359:2105-2120.

21. Lewington S, Clarke R, Qizilbash N, Peto R, Collins R. Age-specific relevance of usual blood pressure to vascular mortality: a meta-analysis of individual data for one million adults in 61 prospective studies. Lancet 2002;360:1903-1913.

22. Franklin SS, Larson MG, Khan SA, Wong ND, Leip EP, Kannel WB, Levy D. Does the relation of blood pressure to coronary heart disease risk change with aging? The Framingham Heart Study. Circulation 2001;103:12451249.

23. Mancia G, Laurent S, Agabiti-Rosei E, Ambrosioni E, Burnier M, Caulfield MJ, et al. Reappraisal of European guidelines on hypertension management: a European Society of Hypertension Task Force document.J Hypertens 2009;27:2121 -2158.

24. O’Brien E, Asmar R, Beilin L, Imai Y, Mallion JM, Mancia G, Mengden T, Myers M, Padfield P, Palatini P,
Parati G, Pickering T, Redon J, Staessen J, Stergiou G, Verdecchia P. European Society of Hypertension recommendations for conventional, ambulatory and home blood pressure measurement. J Hypertens 2003;21: 821848.

25. Verberk W, Kroon AA, de Leeuw PW. Masked hypertension and white-coat hypertension prognosis. J Am Coll Cardiol 2006;47:2127; author reply 2127-2128.

26. Ministarstvo zdravlja Srbije. Istraživanje zdravlja stanovnika republike Srbije. 2013.Izveštaj

27. Cooney MT, Dudina A, De Bacquer D, Fitzgerald A, Conroy R, Sans S, Menotti A, De Backer G, Jousilahti P, Keil U, Thomsen T, Whincup P, Graham I. How much does HDL cholesterol add to risk estimation? A report from the SCORE Investigators. Eur J Cardiovasc Prev Rehabil 2009;16:304-314.

28. Cooney MT, Dudina A, De Bacquer D, Wilhelmsen L, Sans S, Menotti A, De Backer G, Jousilahti P, Keil U, Thomsen T, Whincup P, Graham IM. HDL cholesterol protects against cardiovascular disease in both genders, at all ages and at all levels of risk. Atherosclerosis 2009;206:611-616.

29. https://www.heartscore.org last visit 27/07/2020.

30. UK Prospective Diabetes Study Group. Effect of intensive blood-glucose control with metformin on complications in overweight patients with type 2 diabetes (UKPDS 34). Lancet 1998;352:854-865.

31. Albus C, Jordan J, Herrmann-Lingen C. Screening for psychosocial risk factors in patients with coronary heart disease - recommendations for clinical practice. Eur $\mathbf{J}$ Cardiovasc Prev Rehabil2004;11:75 -79.

32. Rozanski A, Blumenthal JA, Davidson KW, Saab PG, Kubzansky L. The epidemiology, pathophysiology, and management of psychosocial risk factors in cardiac practice: the emerging field of behavioral cardiology. J Am Coll Cardiol 2005;45: 637-651.

33. Kotseva K, Wood D, De Backer G, De Bacquer D, Pyorala K, Keil U. Cardiovascular prevention guidelines in daily practice: a comparison of EUROASPIRE I, II, and III surveys in eight European countries.Lancet2009;373:929-940.

34. Rayner M, Allender S, Scarborough P. Cardiovascular disease in Europe.Eur J Cardiovasc Prev Rehabil2009;16Suppl 2:S43 -S47

35. Cuende JI, Cuende N, Calaveras-Lagartos J. How to calculate vascular age with the SCORE project scales: a new method of cardiovascular risk evaluation. Eur Heart J 2010;31:2351-2358.

36. Conroy RM, Pyorala K, Fitzgerald AP, Sans S, Menotti A, De Backer G, De Bacquer D, Ducimetiere P, Jousilahti P, Keil U, Njolstad I, Oganov RG, Thomsen T, Tunstall- Pedoe H, Tverdal A, Wedel H, Whincup P, Wilhelmsen L, Graham IM. Estimation of ten-year risk of fatal cardiovascular disease in Europe: the SCORE project. Eur Heart J 2003;24:987-1003.

37. Sofi F, Abbate R, Gensini GF, Casini A. Accruing evidence on benefits of adherence to the Mediterranean diet on health: an updated systematic review and meta-analysis. Am J Clin Nutr 2010;92:1189-1196. 
38. Conroy R.M., Pyörälä K., et al. Estimation of ten-year risk of fatal cardiovascular disease in Europe: the SCORE project. European Heart Journal 2003;24:9871003.

39. Lakic D, Tasic Lj, Kos M. Economic burden of cardiovascular disease in Serbia. Vojnosanit Pregled 2014; 71(2): 137-147. 